\title{
Segmentation as a base for digital marketing strategies in blood service: A cluster analysis for classifying healthy regional subjects
}

\author{
Liliia Khomenko ${ }^{1, *}$, Liudmyla Saher ${ }^{1}$, Nataliia Letunovska ${ }^{1}$, and Adam Jasnikowski ${ }^{2}$ \\ ${ }^{1}$ Sumy State University, Department of Marketing, Rimsky Korsakov Str. 2, 40007 Sumy, Ukraine \\ ${ }^{2}$ Director, Fundacja EUROWEEK, Plac Wolności 21, 57-500 Bystrzyca Kłodzka, Poland
}

\begin{abstract}
The work aims to analyse the youth by lifestyle and divide it into segments for more effective interaction in advertising campaigns. The object of the study is young people aged from 18 to 35 living in Sumy, Ukraine. It was performed a cluster analysis using the k-means method in the program Statistica 10 to divide into segments. There were selected 5 clusters. The main parameter for segment division is the age and previous experience of donation or its absence. There are also important: types of family, existence of children, the type of employment, the number of far trips for rest. Demographics is important first and, to a lesser extent, lifestyle. For two clusters it is recommended to use the recruitment strategy; for others retention strategy with aspects considered in this work. The clusters of respondents identified by the authors also provide an opportunity to divide the residents of the study region in relation to the health problems of the location of their residence in relation to life and activities.
\end{abstract}

\section{Introduction}

Blood donation plays an important role in the health care system of any country, and, accordingly, is one of the areas to achieve the sustainable development goals. The preservation of human life sometimes depends on the availability of donor blood or its components. There is a significant shortage of donated blood in the world, which negatively affects the quality and availability of medical care. Ukraine is no exception. Therefore, the analysis of existing and potential donors and their segmentation on its basis is an urgent issue. This will allow taking into account more accurately the characteristics of different categories (segments) in developing marketing programs for recruitment and retention.

The issues of sustainable development, the goals of which meet the popularization of blood centres, are studied by the authors [1-3]. Economic analysis of health care, health management research is carried out in [4-6]. The study of decentralization, its impact on reforms, identification of key elements of competitiveness and sustainable development of regions is described by the authors in [7-11]. The relationship between economic, social development and the Covid-19 pandemic, the impact of the pandemic on various areas of activity, which are the important factors in determining the region's competitiveness and

* Corresponding author: 1.khomenko@,fem.sumdu.edu.ua 
socio-economic development, are discussed in the following publications [12-18]. Information security issues $[19 ; 20]$ in terms of building consumer confidence is one of the elements of marketing strategy in blood service.

The study of socio-economic challenges of sustainable development, business cycles analysis, the use of intersectoral and cross-regional approaches to analysis [21-32] allows deeper understanding of motives of consumers' behaviour, determining what factors influence them in making certain decisions [33-34], more reasonably approaching their segmentation [35] when determining the target group.

Customer analysis and segmentation are important components in the marketing management of blood service facilities [36].

Every year the number of scientific publications on marketing activities in blood service facilities grows [37]. They focus on donor behaviour and motivation [38], marketing tools [39-43] and strategies in the blood service [44], factors influencing donors and understanding of donors' motives [45], segmentation, and work with individual segments [46].

In recent years, there has become more research on segmentation and work with individual donor segments to create promotional activities and engage communications with each segment.

There are a large number of studies on the blood donors division into groups by barriers to be a donor [47], the reasons for refusal to be a donor [48], motivation [49], age characteristics $[47,50,51]$, sphere of activity [52], religious and racial affiliation [53, 54], origin and place of residence [55].

Blood donors' segmentation can occur in one or several variables or even all variables. It allows identifying existing and potential needs and motives of donors; maximizing the benefits of a single donor; successfully competing with blood service facilities.

One of the criteria for the health of the country's population is the availability of blood donors [57]. Blood donation is an essential part of every region's health care system. The state of the donation system in the region is an indicator of society's spiritual and social health. Donation is part of a general concept aimed at implementing the idea of a healthy lifestyle. Attitudes towards donation of most residents, particularly among young people, are taken into account in the general classification of regional subjects if researchers analyse attitudes to the health components of the territory of residence. Developed countries with well-structured blood supply services are generally able to meet all the demand for blood products. Donors are divided into unpaid, paid, and donors who donate blood components when family members need help. With the support of voluntary unpaid donors, almost 80 countries worldwide collect more than $90 \%$ of the amount of blood required at the national level. In nearly 60 countries worldwide, more than $50 \%$ of the blood supply depends on paid blood donors or donors who donate blood to relatives. It should be noted that voluntary donors, motivated solely by altruism when donating their blood, are more interested in maintaining their health at the proper level before the blood drawing and avoid risk factors that could harm a person who will be transfused. Unfortunately, Ukraine is one of the countries where the number of donors is insufficient. The donation problem is not given enough attention to, and even those who would potentially agree to donate blood are full of fear and uncertainty about how safe is a blood drawing procedure. In this case, the real challenge for the country is to find creative recruitment methods to attract new donors on an ongoing basis and promote the need for blood donation to society.

According to the research, young people are a promising target audience for blood service centres, because, having joined the donorship at a young age, a person can be a donor for many years. Young people have better health, including fewer chronic illnesses. Young people have a wide range of communication and influence to attract several new people to the donor movement. 
It is known about the influence of demographic factors on blood donation. In Canada, a correlation was found between blood donation and socio-demographic characteristics. For example, cities with more emigrants have lower recruitment rates. The data on the importance of education in motivating donors are confirmed, so it is more appropriate to turn to more educated groups of the population to recruit them to become donors [58]. In the Netherlands, the difference in demographic factors between regular and occasional donors is confirmed by the fact that men are less likely to refuse blood donation and are 5 times more likely to become regular donors than women. Living in urban areas and high socioeconomic status (high income, expensive housing) predominate among regular blood donors [59].

There are currently no studies on youth segmentation by lifestyle for the blood service. There is also the question of where it is better to post information to draw attention to it. Undoubtedly, the Internet is becoming an increasingly popular source of information about services, businesses, activities. Since the target people of local blood service centres are locals, it is interesting to look at the statistics of the growing popularity of the Internet as a source of information of local companies (except for direct visits to the institution) (see Figure 1).

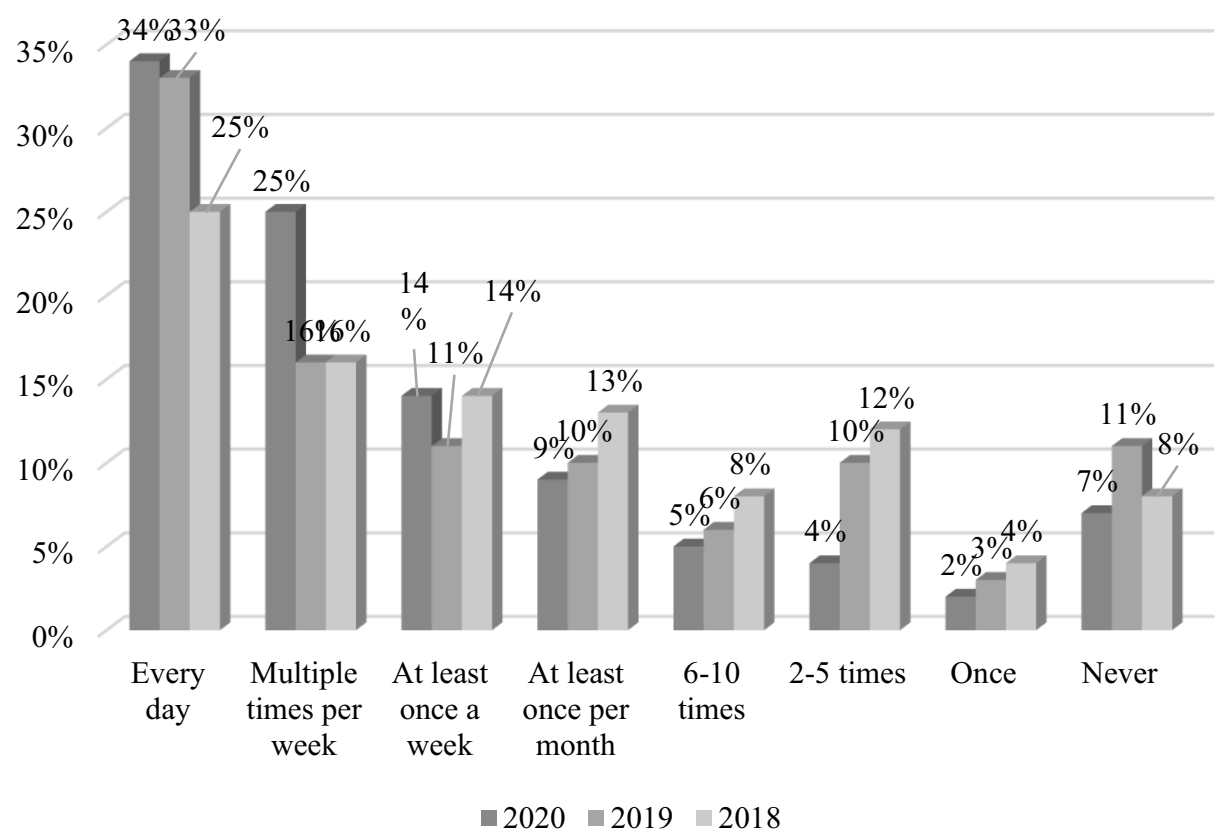

Fig. 1. Frequency of the Internet use by residents to search for information about local companies and services (compiled on [60]].

Figure 1 shows that more than $90 \%$ of residents used the Internet to search for information in 2020 , but with different frequency. It is noteworthy that more than $70 \%$ of respondents use a web search every week and find information about the offer from local businesses. This trend intensified in 2021 during the continuing COVID-19 pandemic, which caused restrictions in many regions of the world. It indicates the growing importance of the role of the Internet marketing in promoting services.

This paper aims to analyse the youth by lifestyle and divide it into segments for more effective interaction with them in advertising campaigns.

The research objectives are: 
- to analyse the young people lifestyle: to find out what characteristics young people have, how and where they look for information, which influences decision-making;

- to identify the most important parameters and investigate their relationship;

- to select segments by the most important parameters;

- to develop proposals for working with individual segments.

The object of the study is young people aged from 18 to 35 living in Sumy (Ukraine).

The subject of the research is the characteristics of potential donors and non-donors, in particular lifestyle.

The research hypothesis is that young people can donate blood longer. It is easier to involve them in the donorship if it is known where they are, how they perceive information, and where they spend their time, whom they consider to be authorities. Understanding these aspects, advertising messages can be targeted at engaging in donorship.

\section{Materials and Methods}

A survey was conducted to analyse the lifestyle of young people. The general population is residents of Sumy aged from 18 to 35 . They amount to 63,661 people [61]. The sample is simple random - 121 people ( $95 \%$ confidence interval, $9 \%$ confidence interval). The research period is December 2020 - May 2021.

The questionnaire included the following questions:

1. Have you ever been a blood or plasma donor?

2. How many times have you donated blood as a donor?

3. Your gender.

4. Your age (complete number of years).

5. Who do you live with: on your own, with your parents, with your spouse, with your children?

6. Do you have children?

7. Do you work or study?

8. How do you usually get to work or study: own or public transport, on foot?

9. How many times a year do you go on distant trips for rest?

10 . Where do you usually shop?

11. What is important for you when receiving services?

12. Which people as an information source do you have the greatest trust in?

13. What communication channels and sources of information do you trust?

14. If you need information about medical services, where will you first look for information?

15. How many hours on average do you spend online per week?

16. What do you use at least 2 times per week: social networks, messengers, YouTube?

17. What do you usually watch on the Internet: video, images, text, and audio?

Three interviewers were invited to conduct the survey. They were provided with a link to the questionnaire on Google Drive and given access to the administrative part of the questionnaire. Questionnaires were distributed by sending a relevant link.

A cluster analysis was performed using the k-means method [62-120] in the program STATISTICA 10 to select the segments. The initial centres of the clusters were sorted by distance; observations were set at constant intervals. We checked the number of clusters from 2 to 10 . The analysis included only 10 single-answer questions.

Different measurements used different types of scales; that's why the data were standardized.

The analysis of variance was performed to determine the most important parameters. Data were analysed for the number of clusters from 2 to 10 . There were used only parameters at which the $\mathrm{p}$-value was much less than 0.05 . There were studied the average values by clusters. 
There were described all clusters and features of interaction with them for marketing purposes.

\section{Results and discussions}

The study includes the data of 121 respondents aged from 18 to 35 years. The main characteristics of the sample are presented in Table 1.

Table 1. The main characteristics of the respondents.

\begin{tabular}{|c|c|c|c|c|}
\hline Indicators & $\begin{array}{c}\text { Frequency, } \\
\text { pers. }\end{array}$ & $\begin{array}{c}\text { Percent of } \\
\text { respondents, \% }\end{array}$ & $\begin{array}{l}\text { Of these donors, } \\
\text { pers. }\end{array}$ & $\begin{array}{l}\text { Percent of the total } \\
\text { number of } \\
\text { respondents, \% }\end{array}$ \\
\hline Total & 121 & 100 & 41 & 33.9 \\
\hline \multicolumn{5}{|l|}{ Gender } \\
\hline Female & 47 & 38.8 & 23 & 19.0 \\
\hline Male & 74 & 61.2 & 18 & 14.9 \\
\hline \multicolumn{5}{|l|}{ Age } \\
\hline Up to 20 years & 61 & 50.4 & 14 & 11.6 \\
\hline $21-25$ years & 34 & 28.1 & 18 & 14.9 \\
\hline $26-30$ years & 8 & 6.6 & 5 & 4.1 \\
\hline $31-35$ years & 18 & 14.9 & 4 & 3.3 \\
\hline \multicolumn{5}{|l|}{ Family type } \\
\hline Single & 41 & 33.9 & 16 & 13.2 \\
\hline Nuclear & 75 & 62.0 & 25 & 20.7 \\
\hline Joint & 4 & 3.3 & 0 & 0.0 \\
\hline Children in the family & & 0.0 & & 0.0 \\
\hline Have children & 22 & 18.2 & 6 & 5.0 \\
\hline Don't have children & 99 & 81.8 & 35 & 28.9 \\
\hline \multicolumn{5}{|l|}{ Study and work } \\
\hline work full or part time & 33 & 27.3 & 15 & 12.4 \\
\hline study & 57 & 47.1 & 16 & 13.2 \\
\hline Don't work & 16 & 13.2 & 6 & 5.0 \\
\hline Combine work and study & 15 & 12.4 & 4 & 3.3 \\
\hline
\end{tabular}

Hierarchical clustering in Statistica 10 was performed to approximate the number of clusters. Objects are strings, the join rule is the whole connection method, and the proximity measures are Euclidean distances. The vertical dendrogram is presented in Fig. 2.

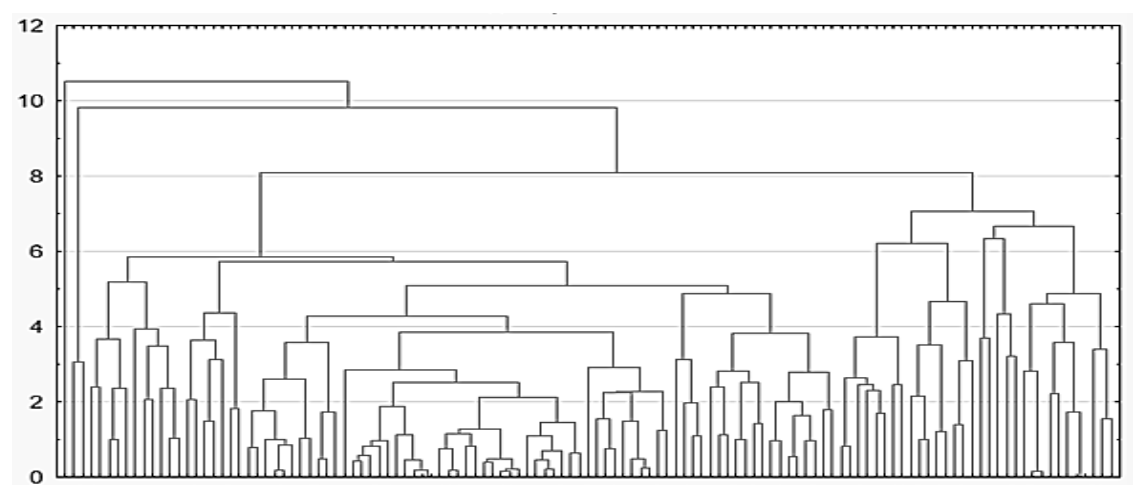

Fig. 2. The vertical dendrogram. 
According to the vertical dendrogram, there are about 5-6 clusters. The data gathered and processed for the needs of Statistica 10 were subjected to cluster analysis of the K-means cluster. It was checked the number of clusters from 2 to 10 . The optimal result was obtained when the number of indicators was 10 , the number of observations was 121 , the number of clusters was 5 , and the result was obtained in 3 iterations. It was stopped at 5 clusters because it was beginning to appear small clusters with 2-4 respondents with a more number. The results of the analysis of variance are shown in Table 2.

Table 2. Analysis of variance for 10 parameters.

\begin{tabular}{|c|c|c|c|c|c|c|}
\hline Indicators & Between SS & Df & Within SS & df & F & p-value \\
\hline $\begin{array}{c}\text { Presence of previous } \\
\text { donation experience }\end{array}$ & 47.23174 & 4 & 72.76826 & 116 & 18.8230 & 0.000000 \\
\hline Number of donations & 57.26285 & 4 & 62.73715 & 116 & 26.4695 & 0.000000 \\
\hline Gender & 61.19218 & 4 & 58.80782 & 116 & 30.1758 & 0.000000 \\
\hline Age & 76.08447 & 4 & 43.91553 & 116 & 50.2430 & 0.000000 \\
\hline Family type & 58.58664 & 4 & 61.41336 & 116 & 27.6652 & 0.000000 \\
\hline The presence of children & 94.53940 & 4 & 25.46060 & 116 & 107.6818 & 0.000000 \\
\hline $\begin{array}{c}\text { Type of employment (work } \\
\text { or study) }\end{array}$ & 23.99958 & 4 & 96.00041 & 116 & 7.2498 & 0.000030 \\
\hline Type of transport & 25.26674 & 4 & 94.73326 & 116 & 7.7347 & 0.000015 \\
\hline Number of far trips for rest & 99.12475 & 4 & 20.87525 & 116 & 137.7046 & 0.000000 \\
\hline $\begin{array}{c}\text { The amount of time on the } \\
\text { Internet per week }\end{array}$ & 26.46356 & 4 & 93.53645 & 116 & 8.2048 & 0.000007 \\
\hline
\end{tabular}

For most indicators, the value of $\mathrm{p}$ goes to 0 or much less than 0.05 . F is actually more critical, big Between SS. Therefore, these indicators are important for research. At the same time, indicators of the type of employment, type of transport and amount of time on the Internet are the least important.

Based on the average distances, it is determined what characteristics each of the clusters has.

Table 3. Middle clusters.

\begin{tabular}{|c|c|c|c|c|c|}
\hline Indicators & Cluster 1 & Cluster 2 & Cluster 3 & Cluster 4 & Cluster 5 \\
\hline $\begin{array}{c}\text { Presence of previous donation } \\
\text { experience }\end{array}$ & 1.80 & 2.00 & 1.00 & 1.00 & 1.71 \\
\hline Number of donations & 0.70 & 0.00 & 3.62 & 13.67 & 1.00 \\
\hline Gender & 1.90 & 1.68 & 1.46 & 1.11 & 1.71 \\
\hline Age & 31.70 & 20.00 & 20.54 & 24.67 & 30.79 \\
\hline Family type & 5.50 & 1.68 & 1.65 & 1.56 & 2.14 \\
\hline The presence of children & 1.10 & 2.00 & 2.00 & 2.00 & 1.07 \\
\hline $\begin{array}{c}\text { Type of employment (work or } \\
\text { study) }\end{array}$ & 2.30 & 3.44 & 3.23 & 1.89 & 2.57 \\
\hline Type of transport & 2.00 & 2.13 & 2.15 & 1.67 & 1.86 \\
\hline $\begin{array}{c}\text { Number of far trips for rest } \\
\text { The amount of time on the } \\
\text { Internet per week }\end{array}$ & 3.90 & 7.74 & 4.38 & 6.56 & 5.57 \\
\hline
\end{tabular}


There was described each of the clusters.

Cluster 1 is represented by 10 respondents $(8 \%)$, most of them aged 35 , mostly women, have a nuclear or joint family, have children, work full-time, get to work on foot or by public transport, go for rest at a distance on average 4 times a year, spend 20 hours a week on the Internet. Most of them have never been blood donors.

$90 \%$ do shopping in supermarkets, $60 \%$ in online stores, $50 \%$ in pharmacies and markets. They have never bought on social media and messengers. When getting service, for $70 \%$ problem solving is important, for $50 \%$ - location, and quality assurance. Families $(60 \%)$, experts $(60 \%)$, and scientists $(30 \%)$ are most trusted. They have never trusted to magazines, social media, and outdoor advertising. To find most trustworthy information, they search in the official company's websites $(50 \%)$, in search engines $(40 \%)$. They look for information about medical services primarily on the Internet (90\%), in medical institutions (60\%). They use at least twice a week Facebook $(80 \%)$ and Viber (80\%), Youtube $(50 \%)$ and Telegram $(50 \%)$, Instagram $(40 \%)$, and Tik-Tok $(10 \%)$. They are most often viewed on the Internet texts $(80 \%)$ and images $(60 \%)$.

Cluster 2 is represented by 62 respondents (51\%). The majority aged from 18 to 21 , both men and women, live either alone or with parents, have no children, most study, rarely studies and work, get to work or school by public transport, rarely on foot, most go for distant rest up to 5 times a year, spend 30 hours a week on the Internet. Most of them have never been blood donors.

They do shopping in supermarkets $(90 \%)$, in shops $(71 \%)$, in pharmacies $(54 \%)$, online stores $(43 \%)$, as well as in social networks $(29 \%)$, groups in messengers $(13 \%)$. When receiving the service, the most important are quality assurance $(62 \%)$, location and convenient forms of communication (58\% each), pleasant staff $(53 \%)$, problem-solving $(50 \%)$. Experts (64\%), family (57\%), scientists (32\%), and friends (29\%) are the most trusted. They look for most trustworthy information on social networks (53\%), search engines (39\%), the company's official websites (31\%), and blogs (29\%). They look for information about medical services primarily in medical institutions $(65 \%)$, on the Internet $(57 \%)$, ask parents (44\%). At least 2 times a week, they use Telegram (89\%), Youtube (84\%), Instagram (82\%), Viber (53\%), Tik-Tok (40\%), Facebook (30\%). $84 \%$ watch videos on the Internet, $62 \%$ watch images, and $50 \%$ read texts.

Cluster 3 is represented by 27 respondents (22\%), aged from 18 to 22 , men and women, living alone or with parents, have no children, majority study, a half works, gets to work or study by public transport or on foot, most go for a distant rest up to 3 times a year, most spend online up to 30 hours a week. Most were blood donors, on average, 4 times.

They shop in supermarkets $(82 \%)$ and shops $(78 \%)$, less often in pharmacies $(41 \%)$, markets, and online stores ( $37 \%$ each). When receiving the service, the most important thing is a guarantee of quality (74\%) and pleasant staff (56\%), problem-solving (54\%), as well as location $(37 \%)$, and convenient forms of communication $(37 \%)$. The opinions of experts (67\%), family members (44\%) and scientists (44\%), friends and acquaintances $(37 \%)$ are the most trustworthy. They look for the most trustworthy information in search engines $(52 \%)$, thematic sites $(41 \%)$, and official sites $(33 \%)$. They look for information about medical services primarily in medical institutions $(70 \%)$, the Internet $(56 \%)$, or ask from parents (37\%). They use Instagram (89\%), Telegram (78\%), Youtube (70\%), Viber (52\%), Facebook (41\%), Tik-Tok (37\%) at least 2 times a week. $82 \%$ of them watch the video, $70 \%$ listen to audio and read texts on the Internet.

Cluster 4 is represented by 9 respondents (7\%). The average age is 23 years; these are men, living alone or with parents, no children, work full-time, study less often, half get to work by their own transport, others on foot or by public transport, go for a distant rest on average 6 times a year, spend 30 hours a week on the Internet. All of them were blood donors 14 times, on average. 
They make purchases in shops (89\%), in supermarkets (67\%), in online stores (33\%), and on markets $(22 \%)$. They never buy on social networks and groups in messengers. It is important for $67 \%$ to solve problems when receiving the service, guarantee the quality and pleasant staff (56\% each). Respondents trust the most to experts $(67 \%)$, family $(56 \%)$, friends or acquaintances (44\%). The most trusted information for them is from thematic sites and blogs $(33 \%)$. And they never trust the information on television, in magazines, official websites of companies, indoor advertising. They look for information about medical services primarily on the Internet (89\%), less often ask parents (33\%). At least 2 times a week, they use Instagram, Telegram (78\%), Youtube (67\%), less Viber (44\%), Tik-Tok (22\%), Facebook (11\%). 44\% read texts and $56 \%$ watch videos on the Internet.

Cluster 5 is represented by 14 respondents (12\%). Most of them are aged 27-35, mostly women, living alone or having nuclear family, with children; most work full-time or parttime, a third is unemployed, a half get to work by own transport, go for a distant rest on average 5-6 times a year, spend an average of 11 hours a week on the Internet. Most of them have never been blood donors.

$79 \%$ do shopping in supermarkets, $64 \%$ - in shops, $57 \%$ - in online stores, and $14 \%$ - in groups in messengers. When they receive the service, for $64 \%$ it is important to get a solution, for $43 \%$ the important is quality assurance. Experts are most trusted (79\%), family (36\%), and friends $(29 \%)$ are less trusted. Most trustworthy information is found on blogs and search engines (43\%), the company's official websites (36\%), television (21\%), and social networks $(21 \%)$. They look for information about medical services primarily in medical institutions (71\%), the Internet (64\%), and ask friends (57\%). At least 2 times a week they use Telegram (71\%), Instagram (64\%), Youtube (57\%), Viber (50\%), Facebook (29\%), WhatsApp (21\%), Tik-Tok (14\%). $81 \%$ read texts and $50 \%$ watch videos on the Internet.

The adequacy of the model was verified by repeated clustering by other methods: squares of Euclidean distances, Manhattan distance, Chebyshev distances, and 1-r Pearson. Vertical dendrograms have almost the same form as shown in Fig. 1. It was concluded about the adequacy of the model.

\section{Discussion and conclusion}

There were identified 5 clusters among young people by their lifestyle in work.

The main parameter for segment division is the age and previous experience of blood donation or its absence. There are also significant types of family, the presence of children, the type of employment, and the number of distant trips for rest. Demographics is important first and, to a lesser extent, lifestyle.

Clusters 2 and 3 are very similar in most parameters, differing only in the amount of the distant trips for rest during the year and previous blood donation experience.

Clusters 2 and 5 for the blood service facility are the most difficult because their representatives have no blood donation experience. To work with them, the blood centre needs to use a recruitment strategy. Other clusters have previous blood donation experience, so it is advisable to use a retention strategy for them.

It is advisable to use a recruitment strategy to work with cluster 1. It needs to put an emphasis on location and a guarantee of high quality. Experts and scientists can be referred to in the reports. There should be enough information on the official website. Also, contextual advertising can be used. It is advisable to use Facebook and Viber to maintain further communications. All messages have to be accompanied by images and text.

A half of the respondents belong to cluster 2, who are the most attractive in terms of capacity. The blood centre needs to emphasize in advertising messages the guarantee of high quality, convenient location, and forms of communication to work with them. This information should be provided on behalf of experts and disseminated through social 
networks, contextual advertising, the official website, Youtube channel, thematic sites, blogs of experts, and opinion leaders. All information should be in a video format, with more images, accompanied by a text description. It is advisable to keep in touch with them in the future via Telegram or Viber, Instagram, or Tik-Tok.

Cluster 3 presents donors who are similar in characteristics to cluster 2 but have previous blood donation experience. Blood centres can use the same tools for cluster 2, but there must be a retention strategy. They can add an information format - audio.

To work with cluster 4 , it is necessary to use a retention strategy. There must be expert comments to emphasize high quality. Information should be posted on thematic sites and blogs. It is advisable to keep in touch with them in the future via Instagram and Telegram. All information should be in video and text formats.

It is recommended to use the recruitment strategy to work with cluster 5, emphasizing the importance of helping others, guaranteeing safety and high quality. Messages should be on behalf of experts, use contextual advertising, impact marketing, official website, social networks. It is advisable to keep in touch with them in the future via Telegram or Viber, Instagram, or Facebook. All information should be in text and video formats.

People aged from 23 to 30 were grouped into cluster 4 , which is the smallest. This is probably due to the small number of these age group respondents in this study. Therefore, this category needs further research.

It is advisable to do additional, more extensive research to consolidate the clusters and confirm the new hypotheses. Therefore, in the future, it is necessary to perform a further study among a greater number of participants, evenly represented in all age categories, which will result in less error.

The findings of this study can be used by blood centres in developing advertising campaigns for young people.

\section{References}

1. M.P. Bhandari, K. Bhattarai. SocioEconomic Challenges, 1(3), 6-21 (2017).

2. L. Yiu, R. Saner, R. Bardy. Business Ethics and Leadership, 4(4), 14-27 (2020).

3. B. Suarez, A. Vargas. SocioEconomic Challenges, 5(1), 13-27 (2021).

4. N. Letunovska, L. Saher, T. Vasylieva, S. Lieonov. Paper presented at the E3S Web of Conferences, 250 (2021).

5. A. Shipko, N. Demikhova, K. Pajak, V. Motrechko. Health Economics and Management Review, 1(2), 8-16 (2020).

6. M. Grabowska, D.Kolesnyk, O. Matlai. Health Economics and Management Review, 1(1), 60-68 (2020).

7. N. Letunovska, O. Lyuolyov, T. Pimonenko, V. Aleksandrov. Paper presented at the E3S Web of Conferences, 234 doi:10.1051/e3sconf/202123400008.

8. I. Aghasiev, N. Pavlikha, N. Riabushenko. Business Ethics and Leadership, 2(3), 21-33 (2018).

9. O. Bilovodska, O. Gryshchenko, L. Syhyda. Marketing and management of innovations. 2, 73-79 (2016).

10. L. Saher, L. Syhyda, O. Korobets, T. Berezianko. Paper presented at the E3S Web of Conferences, , 234 doi:10.1051/e3sconf/202123400011

11. Y. Petrushenko, N. Kostyuchenko, D. Smolennikov, A. Vorontsova, Problems and Perspectives in Management, 15(3), 183-192 (2017). 
12. G. Hinrichs, H. Bundtzen. Financial Markets, Institutions and Risks, 5(1), 80$86(2021)$.

13. I. Vakulenko, L. Saher, L. Syhyda, S. Kolosok, A. Yevdokymova. Paper presented at the E3S Web of Conferences, 234 (2021) doi:10.1051/e3sconf/202123400020

14. O. Kuzmenko, T. Vasylieva, S.Vojtovič, O. Chygryn, V. Snieška. Economics and Sociology, 13(4), 318-340 (2020).

15. V. A. Smiianov, O. V. Lyulyov, T. V. Pimonenko, T. A. Andrushchenko, S. Sova, N. V. Grechkovskaya. Wiadomosci Lekarskie, 73(11), 2332-2338 (2020).

16. A. Bondarenko, L. Zakharkina, L. Syhyda, L. Saher. International Journal of Sustainable Development and Planning, 15(4), 439-449 (2020). doi:10.18280/ijsdp. 150404.

17. V.A. Smiianov, T.A. Vasilyeva, O.Y. Chygryn, P.M. Rubanov, T.M. Mayboroda. Wiadomosci Lekarskie, 73(10), 2181-2187 (2020).

18. Y. Kharazishvili, A. Kwilinski, O. Grishnova, H. Dzwigol, Sustainability, 12(21), 8953 (2020)

19. H. Yarovenko, Y. Bilan, S. Lyeonov, G. Mentel. Journal of Business Economics and Management, 22(2), 369-387 (2021).

20. H. Yarovenko. Problems and Perspectives in Management, 18(3), 195-210 (2020).

21. O. Chigrin, T. Pimonenko. International Journal of Ecology and Development, 29(3), $1-13(2014)$

22. H. Dzwigol, M. Dzwigol-Barosz, Z. Zhyvko, R. Miskiewicz, H. Pushak, Journal of Security and Sustainability Issues, 8(3), 307-317 (2019)

23. O. Chygryn, A. Rosokhata, O. Rybina, N. \& Stoyanets. Green competitiveness: The evolution of concept formation. Paper presented at the E3S Web of Conferences, , 234 (2021). doi:10.1051/e3sconf/202123400004

24. O. Lyulyov, T. Pimonenko, A. Kwilinski, H. Dzwigol, M. Dzwigol-Barosz, V. Pavlyk, P. Barosz, Energies, 14(2) (2021)

25. A. Rosokhata, M. Minchenko, L. Khomenko, O. Chygryn. Paper presented at the E3S Web of Conferences, , 250 (2021) doi:10.1051/e3sconf/202125003002

26. J. Cebula, O. Chygryn, S. Chayen, V., T. Pimonenko. International Journal of Environmental Technology and Management, 21(5-6), 421-438 (2018). doi:10.1504/IJETM.2018.100592

27. R. Miskiewicz, Energies, 13(22), 6106 (2020)

28. A. Vorontsova, T. Vasylieva, Y. Bilan, G. Ostasz, T. Mayboroda, Administratie Si Management Public, 2020(34), 6-26 (2020).

29. Y. Petrushenko, A. Vadym, A. Vorontsova, O. Ponomarenko. Sustainable development goals as a tool for strategic planning in communities: A bibliometric analysis of research, in Proceedings at the E3S Web of Conferences, 202 (2020).

30. A. Vorontsova, H. Shvindina, T. Mayboroda, H. Mishenina, I. Heiets. Problems and Perspectives in Management, 18(4), 275-288 (2020).

31. T. Vasilyeva, S. Bilan, K. Bagmet, R. Seliga. Economics and Sociology, 13(1), 271294 (2020).

32. A. Artyukhov, I. Volk, T. Vasylieva, S. Lyeonov. The role of the university in achieving SDGs 4 and 7: A Ukrainian case, in Proceedings at the E3S Web of Conferences, 250 (2021). 
33. M.J. Salé, O. Muharremi, M. Hoxhaj. Business Ethics and Leadership, 5(1), 6680 (2021).

34. K. Nemmiche, Ab. Nassour, M. Bouchetara. Financial Markets, Institutions and Risks, 3(4), 16-23 (2019).

35. A. Verdenhofs, , T. Tambovceva. Marketing and Management of Innovations, 1, 238243 (2019).

36. L.M. Khomenko. Segmentation for Consumers of Small and Medium Blood Service Enterprises, in Proceedings of the International Scientific Online Conference "Innovation, Social and Economic Challenges", Sumy, SumDU, 69-72 (2020).

37. L. Khomenko, L. Saher, J. Polcyn. Health Economics and Management Review, 1, 2036. (2020).

38. T.W. Gillespie, C.D. Hillyer.Transfusion Medicine Reviews, 16(2), 115-130 (2002).

39. V. Goktas, E. Erol, R. Altunisik, K. Ardic. Marketing and Management of Innovations, 2, 21-32 (2019).

40. A. Teletov, S. Teletova, N. Letunovska. Periodicals of Engineering and Natural Sciences, 7(2), 458-465 (2019).

41. A. Rosokhata, O. Rybina, A. Derykolenko, V. Makerska. Research in World Economy, 11 (4), 42-52 (2020).

42. O. Chygryn, O. Lyulyov, T. Pimonenko, S. Mlaabdal. Engineering Management in Production and Services, 12(4), 92-104 (2020). doi:10.2478/emj-2020-0030.

43. S. K. Ahmed, M. M. Khan, R. A. Khan, B.G. Mujtaba. Marketing and Management of Innovations, 1, 40-53 (2020).

44. M.A. Wakefield, B. Loken, R.C. Hornik. The Lancet, 376, 1261-1271 (2010).

45. C.M. Dupin, S. Deubelbeiss, K.D.S. Rodrigues, D. Morais De Oliveira, C. Thentz, M. Quilleau. Recherche En Soins Infirmiers, 136, 16-27 (2019).

46. J.K. Makin, K.L. Francis, M.L. Polonsky, A.M.N. Renzaho. Journal of Environmental and Public Health, 6810959 (2019).

47. J.D. Martin-Santana, A. Beerli-Palacio, L. Romero-Dominguez. Vox Sanguinis, 1(115), 47-59 (2020).

48. E. Senaldi. Annals of Blood, 4, 19 (2019). doi: 10.21037/aob.2019.07.04

49. J.D. Martin-Santana, E. Reinares-Lara, P. Reinares-Lara. Journal of Nonprofit \& Public Sector Marketing, 1(30), 52-73 (2018).

50. S. Nuraini, M.S. Mastura, W.M. Wan Haslindawani, A.T.D. Sharifah. Malaysian Journal of Medicine and Health Sciences, 15, 7-14 (2019).

51. G. Cicolini, D. Comparcini, S. Alfieri, E. Zito, E. Marta, M. Tomietto, V. Simonetti. Journal of Clinical Nursing, 28, 9-10 (2019).

52. A. Agrawal. Global Journal of Transfusion Medicine, 1(2), 69 (2016).

53. J. K. Makin, K. L. Francis, M. J. Polonsky. Journal of Environmental and Public Health, Article ID 6810959 (2019).

54. L. S. Bachegowda, B. Timm, P. Dasgupta, C. D. Hillyer, D. Kessler., M. Rebosa, C.R. France, B.H. Shaz. Transfusion. (6)57. 1515-1521 (2017).

55. A. Ferdous, M. Polonsky, B. Brijnath, A. Renzaho. Designing social marketing activities to impact on shaping expectations of migrants health service encounters: The case of African Migrant blood donation in Australia, in Wymer, Innovations in Social Marketing and Public Health Communication. Cham, Switzerland: Springer, 349-364 (2015). DOI: 10.1007/978-3-319-19869-9_20 
56. State Statistics Service of Ukraine. Available from http://www.ukrstat.gov.ua/ (2019).

57. Global status report on blood safety and availability. Geneva: WHO. (2017).

58. P.J. Saberton, A. Paez, K.B. Newbold et al. Int. J. Health Geogr., 8, 56. (2009).

59. I.J. Veldhuizen, C.J. Doggen, F. Atsma et al. Vox. Sang., 97(2), 129-138 (2009).

60. Local Consumer Review Survey 2020. Available from https://www.brightlocal.com/research/local-consumer-review-survey/ (2020).

61. M. Dove, A. Balasubramanian, B.G. Narayanan. SocioEconomic Challenges, 4(4), 48$62(2020)$.

62. M. Soliman, O. Lyulyov, H. Shvindina, R. Figueiredo, T. Pimonenko. European Journal of Tourism Research, 28 (2021)

63. Y. Us, T. Pimonenko, O. Lyulyov. Polityka Energetyczna, 23(4), 49-66 (2021). doi:10.33223/epj/127397

64. K. Pająk, O. Kvilinskyi, O. Fasiecka, R. Miskiewicz, Economics and Environment, 2(61), 122-138 (2017)

65. S. Cyfert, A. Chwiłkowska-Kubala, W. Szumowski, R. Miśkiewicz, PLoS ONE, 16(4), e0249724 (2021)

66. B. Czyżewski, A. Matuszczak, R. Miskiewicz, Technological and Economic Development of Economy, 25(1), 82-102 (2019)

67. H. Dzwigol, M. Dzwigol-Barosz, R. Miskiewicz, A. Kwilinski, Entrepreneurship and Sustainability Issues, 7(4), 2630-2644 (2020)

68. E. Gross-Golacka, M. Kusterka-Jefmanska, R. Miskiewicz, B. Jefmanski, A. Rzepka, T. Kupczyk, European Research Studies Journal, XXIV(2B), 410-429 (2021)

69. L. Hrytsenko, I. Boiarko, O. Tverezovska, J. Polcyn, R. Miskiewicz, Marketing and Management of Innovations, 2, 155-165 (2021)

70. R. Miskiewicz, Polityka Energetyczna, 21(2), 49-62 (2018)

71. R. Miskiewicz, Virtual Economics, 2(2), 37-47 (2019)

72. R. Miskiewicz, Marketing and Management of Innovations, 3, 371-381 (2020)

73. R. Miśkiewicz, Journal of Risk and Financial Management, 14(2), 59 (2021)

74. R. Miśkiewicz, R. Wolniak, Sustainability, 12(14), 5776 (2020)

75. O. Prokopenko, R. Miskiewicz, Entrepreneurship and Sustainability Issues, 8(2), 269284 (2020)

76. A. Rzepka, R. Borowiecki, R. Miskiewicz, Z. Olesinski, European Research Studies Journal, XXIV(2), 1149-1162 (2021)

77. P.W. Saługa, K. Szczepańska-Woszczyna, R. Miśkiewicz, M. Chłąd, Energies, 13(18), 4833 (2020)

78. H. Dźwigoł, Virtual Economics, 4(1), 98-117 (2021)

79. H. Dzwigol, Marketing and Management of Innovations, 1, 128-135 (2020)

80. H. Dzwigol, Academy of Strategic Management Journal, 19(4), 1-8 (2020)

81. H. Dzwigol, Marketing and Management of Innovation, 1, 324-335 (2021)

82. H. Dzwigol, R. Wolniak, Przemysl Chemiczny, 97(7), 1114-1116 (2018)

83. H. Dzwigol, M. Dzwigol-Barosz, Academy of Strategic Management Journal, 19(5), 17 (2020)

84. H. Dzwigol, S. Shcherbak, M. Semikina, O. Vinichenko, V. Vasiuta, Academy of Strategic Management Journal, 18(SI1), 1-8 (2019) 
85. H. Dzwigol, O. Aleinikova, Y. Umanska, N. Shmygol, Y. Pushak, Journal of Entrepreneurship Education, 22(1S), 1-7 (2019)

86. H. Dzwigol, M. Dźwigoł-Barosz, A. Kwilinski, International Journal of Entrepreneurship, 24(1), 1-5 (2020)

87. Y. Kharazishvili, A. Kwilinski, O. Sukhodolia, H. Dzwigol, D. Bobro, J. Kotowicz, Energies, 14(8), 2126 (2021)

88. Y. Kharazishvili, A. Kwilinski, H. Dzwigol, V. Liashenko, Virtual Economics, 4(2), 7$40(2021)$

89. A. Kwilinski, O. Vyshnevskyi, H. Dzwigol, Journal of Risk and Financial Management, 13(7), 142 (2020)

90. O. Lyulyov, I. Vakulenko, T. Pimonenko, A. Kwilinski, H. Dzwigol, M. DzwigolBarosz, Energies, 14(12), 3497 (2021)

91. H. Dzwigol, M. Dźwigoł-Barosz, Financial and Credit Activity: Problems of Theory and Practice, 2(25), 424-437 (2018)

92. A. Kwilinski, H. Dzwigol, V. Dementyev, International Journal of Entrepreneurship, 24(1), 1-5 (2020)

93. O. Arefieva, O. Polous, S. Arefiev, V. Tytykalo, A. Kwilinski, IOP Conference Series: Earth and Environmental Science, 628, 012039 (2021)

94. V. Boiko, A. Kwilinski, M. Misiuk, L. Boiko, Economic Annals-XXI, 175(1-2), 68-72 (2019)

95. S. Bogachov, A. Kwilinski, B. Miethlich, V. Bartosova, A. Gurnak, Entrepreneurship and Sustainability Issues, 8(2), 487-499 (2020)

96. O. Chygryn, Y. Bilan, A. Kwilinski, Marketing and Management of Innovations, 3, 356-368 (2020)

97. N. Dalevska, V. Khobta, A. Kwilinski, S. Kravchenko, Entrepreneurship and Sustainability Issues, 6(4), 1839-1860 (2019)

98. V.V. Dementyev, A. Kwilinski, Journal of Institutional Studies, 12(1), 100-116 (2020)

99. A. Kuzior, A. Kwilinski, V. Tkachenko, V. Entrepreneurship and Sustainability, 7(2), 1353-1376 (2019)

100.A. Kuzior, A. Kwilinski, I. Hroznyi, Energies, 14(9), 2572 (2021)

101.A. Kuzior, O. Lyulyov, T. Pimonenko, A. Kwilinski, D. Krawczyk, Sustainability, 13(15), 8145 (2021)

102.A. Kwilinski, Virtual Economics, 1(1), 7-25 (2018)

103.A. Kwilinski, Marketing and Management of Innovations, 4, 116-128 (2018)

104. A. Kwilinski, Academy of Accounting and Financial Studies Journal, 23(SI2), 1-6 (2019)

105.A. Kwilinski, V. Tkachenko, A. Kuzior, Journal of Security and Sustainability Issues, 9(2), 561-570 (2019)

106.A. Kwilinski, N. Dalevska, S. Kravchenko, I. Hroznyi, I. Kovalenko, Journal of Entrepreneurship Education, 22(SI1), 1-7 (2019)

107.A. Kwilinski, I. Ruzhytskyi, V. Patlachuk, O. Patlachuk, B. Kaminska, Journal of Legal, Ethical and Regulatory Issues, 22(SI2), 1-6 (2019)

108.A. Kwilinski, R. Volynets, I. Berdnik, M. Holovko, P. Berzin, P. Journal of Legal, Ethical and Regulatory Issues, 22(SI2), 1-6 (2019) 
109.A. Kwilinski, K. Pajak, O. Halachenko, S. Vasylchak, Y. Pushak, P. Kuzior, Marketing and Management of Innovations, 4, 172-181 (2019)

110.A. Kwilinski, A. Kuzior, Management Systems in Production Engineering, 28(2), 119$123(2020)$

111.A. Kwilinski, Y. Zaloznova, N. Trushkina, N. Rynkevych, E3S Web of Conferences, 168, 00031 (2020)

112.A. Kwilinski, M. Dielini, O. Mazuryk, V. Filippov, V. Kitseliuk, Journal of Security and Sustainability Issues, 10(1), 345-358 (2020)

113.A. Kwilinski, I. Slatvitskaya, T. Dugar, L. Khodakivska, B. Derevyanko, International Journal of Entrepreneurship, 24(1 Special Issue), 1-8 (2020)

114.A. Kwilinski, V. Litvin, E. Kamchatova, J. Polusmiak, D. Mironova, International Journal of Entrepreneurship, 25(1), 1-8 (2021)

115.Y. Kyrylov, V. Hranovska, V. Boiko, A. Kwilinski, L. Boiko, L. Journal of Risk and Financial Management, 13(12), 303 (2020)

116.O. Lyulyov, T. Pimonenko, A. Kwilinski, Y. Us, E3S Web of Conferences, 250, 03006 (2021)

117.T. Savchenko, N. Basiurkina, O. Rodina, A. Kwilinski, Management Theory and Studies for Rural Business and Infrastructure Development, 41(1), 43-61 (2019)

118.V. Tkachenko, A. Kwilinski, M. Klymchuk, I. Tkachenko, Management Systems in Production Engineering, 27(2), 119-123 (2019)

119.V. Tkachenko, A. Kuzior, A. Kwilinski, Journal of Entrepreneurship Education, 22(6), 1-10 (2019)

120.J. Polcyn, Sustainability, 13(15), 6846 (2021) 